\title{
Technical Efficiency and Technological Gaps of Rice Production in Anambra State, Nigeria
}

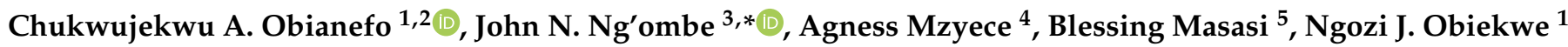 \\ and Oluchi O. Anumudu ${ }^{1}$
}

Citation: Obianefo, C.A.; $\mathrm{Ng}^{\prime}$ ombe, J.N.; Mzyece, A.; Masasi, B.; Obiekwe, N.J.; Anumudu, O.O. Technical Efficiency and Technological Gaps of Rice Production in Anambra State, Nigeria. Agriculture 2021, 11, 1240. https: / / doi.org/10.3390/ agriculture 11121240

Academic Editors: Vítor João Pereira Domingues Martinho, Paulo

Reis Mourão and

Nikolaos Georgantzis

Received: 2 November 2021

Accepted: 1 December 2021

Published: 8 December 2021

Publisher's Note: MDPI stays neutral with regard to jurisdictional claims in published maps and institutional affiliations.

Copyright: (c) 2021 by the authors. Licensee MDPI, Basel, Switzerland. This article is an open access article distributed under the terms and conditions of the Creative Commons Attribution (CC BY) license (https:/ / creativecommons.org/licenses/by/ $4.0 /)$.
1 Department of Agricultural Economics and Extension, Nnamdi Azikiwe University, Enugu-Onitsha Expressway, Awka P.M.B 5025, Anambra State, Nigeria; obianefoca@gmail.com (C.A.O.); engeefelbon@gmail.com (N.J.O.); anumuduoluchi21@gmail.com (O.O.A.)

2 IFAD Assisted Value Chain Development Programme, ADP Complex, Enugu-Onitsha Expressway, Awka P.M.B 5051, Anambra State, Nigeria

3 Department of Agribusiness, Applied Economics, and Agriscience Education, North Carolina A\&T State University, Greensboro, NC 27411, USA

4 Department of Economics, Agriculture and Social Sciences, California State University, Stanislaus, Turlock, CA 95382, USA; agness.mzyece@iw.edu

5 Department of Agriculture, University of Arkansas at Pine Bluff, Pine Bluff, AR 71601, USA; masasib@uapb.edu

* Correspondence: ngombe@okstate.edu

\begin{abstract}
The traditional approach to modeling productive efficiency assumes that technology is constant across the sample. However, farms in different regions may face different production opportunities, and the technologies they employ may differ due to environmental factors. Therefore, rather than using a traditional stochastic frontier model in such cases, a stochastic meta-frontier (SMF) analysis is recommended to account for environmental factors between regions. It follows that differences in environmental factors between the upland and lowland regions in Anambra State, Nigeria, may result in farmers producing rice under different production and environmental conditions. Using the SMF model, this study, for the first time, determines technical efficiency (TE) and technological gap ratios (TGRs) of rice production from the upland and lowland regions in the Awka North Local Government Area of Anambra State, Nigeria. Our data are from a cross-section sample of randomly selected rice farmers. Results reveal that lowland regional rice producers are on average, significantly more technically efficient $(91.7 \%)$ than their upland counterparts (84.2\%). Additionally, mean TGRs associated with lowland rice farmers are higher (92.1\%) than their corresponding upland producers $(84.7 \%)$. While the upland rice producers are less technically efficient and further away from their full potential, results indicate that both sets of farmers do not use advanced technologies to match the industry's potential. We suggest that agricultural policy should focus on providing regionally specific technologies, such as improved rice varieties that fit the working environment of the lagging area, to help rice farmers improve their resource efficiency and minimize technological gaps.
\end{abstract}

Keywords: efficiency measurement; stochastic meta-frontier; rice

\section{Introduction}

Agriculture continues to be the key to economic development for many countries [1-5]. In Nigeria, Ike and Ugwumba [6], Egbetokun et al. [7], and Obianefo et al. [8] contend that no less than $70 \%$ of Nigerians earn their living from the agricultural sector. Moreover, the agricultural sector in Nigeria is subdivided into four important sub-sectors which include crop production, fisheries, aquaculture, and forestry. Rice production is notably an important part of the crop production sub-sector [9]. The case of rice production in Nigeria is similar to other countries in Asia [10] and Africa [11,12] where rice production continues to play an important role in their economic development process as a staple food for most farm families [13]. Therefore, the provision of sufficient rice quantities and affordable 
rice prices are some of the top priorities of Nigeria's national development plan. At the time of this study, Nigeria has made efforts to attain self-sufficiency in rice production through banning rice importation to encourage local production and consumption with the immediate effect of raising the local rice price. Following Obianefo et al. [8] and the World Bank [14], Nigeria has four ecologies (rainfed upland, shallow swamp and inland valley swamp, irrigated lowland, and mangrove or tidal swamp) where rice has been found to thrive very well. However, Nigeria's agricultural sector is dominated by smallholder farmers that often contribute to its stagnation [15].

A large number of smallholder farmers in Nigeria's rice production continuously threatens food security, self-sufficiency in food production, and supply. This is because smallholder farmers are resource-poor and often face the following challenges: the high cost of inputs, the lack of agrochemicals for pests and diseases, the high cost of labor, and limited access to irrigation facilities for year-round farming [16]. The Federal Ministry of Agriculture and Rural Development (FMARD) and the International Fund for Agricultural Development (IFAD) reiterate that rice production by smallholder farmers is challenged by inefficiency in resource allocation, low productivity, poor access to improved varieties, and a heavy reliance on traditional technology, among others [17].

Therefore, to match rice demand with its supply in Nigeria, there is a need to build farmer's capacity in a way to not only produce rice in the upland system but also ensure they equally undertake irrigated (lowland) rice farming while adopting improved technology [18]. Rohmad and Praptiningsih [19] and Willybrordus [20] considered upland rice farming as rice production on dry-land that depends on rainfall for water supply or water supply through irrigation, and that the yield of upland rice farming is still low across many countries. Yurkushi [21] contended that upland rice in Nigeria is the second most important rice production system and that it depends heavily on the amount of rainfall. Continuous heavy downpours lead to nutrient loss through leaching, soil erosion, and flooding. On the other hand, lowland rice is the most prominent rice ecological system in Nigeria covering about $53 \%$ of the rice area [21]. The two types of lowland crop-related technologies are shallow fadama and deep fadama. Fadama generally refers to the land that is capable of being irrigated; the distinguishing feature from upland is that the soil is completely covered with water at some stage or rice growth cycle.

These differences in environmental factors between the upland and lowland suggest that with other factors held constant, rice farmers across the two agro-ecological regions may produce rice under different production and environmental conditions. Following $\mathrm{Ng}^{\prime}$ ombe [22], such differences in regional endowments of resources have the potential to inhibit (motivate) farmers in either region from (to) selecting the best technology from an array of potential technologies. These differences would result in technology gap ratios (TGRs) that may help policymakers to realize which agro-ecological regions need their urgent involvement in improving productivity and technical efficiency (TE). Considering this important issue, the objective of this study is to determine the TE of rice production in the Awka North Local Government Area of Anambra State, Nigeria. We do so by identifying regional-specific frontiers and the rice industry frontier in the study area. We further decompose production efficiency scores into meta-technical efficiency (MTE) and TGRs to unearth how far rice-producing farm households' productions functions are from the stochastic meta-frontier. Additionally, we identify the determinants of technical inefficiency of the rice industry in the area. We do so by using stochastic meta-frontier (SMF) techniques and data sampled from the two areas with distinct environmental factors in Anambra State, Nigeria.

Previous studies have closely determined the production performance of rice producers in Nigeria, other countries in sub-Saharan Africa (SSA), and other world regions. For example, a descriptive study by Umar et al. [18] examined how entrepreneurship and innovation by farmers improve lowland rice farming in Mattiro Ade, Patampanua District, Pinrang Regency, and South Sulawesi Province. Another study by Mariko et al. [23] compared the TE of a system of rice intensification (SRI) and conventional rice production 
system (CRPS) in Mali by applying SMF techniques. Mariko et al. [23] found that mean TE was 0.96 and 0.79 for SRI and CRPS, respectively, while the mean TGR was 0.98 and 0.91 for SRI and CRPS, respectively, with industrial TE averaging 0.858 . Their study further found that labor, farm size, and fertilizer are the significant variables to the meta-frontier, while determinants of technical inefficiency were gender, age, level of education, and farming experience.

Moreover, Obianefo et al. [9] investigated the technical efficiency of rice farmers in the Anambra State value chain development program and found that farmers were operating around $15 \%$ below their optimum potentials. In their study, seed, agrochemical, farm size, labor, and capital input were statistically significant to the production frontier. In the same vein, it was gathered that the variables of inefficiency were gender and farming experience. A study by $\mathrm{Ng}^{\prime}$ ombe [22] on the technical efficiency of smallholder maize production in Zambia used stochastic meta-frontier techniques and established that the socioeconomic variables that influenced technical inefficiency were gender, farming experience, and contact with extension agents, among others. $\mathrm{Ng}^{\prime}$ ombe [22] further found that several regions in Zambia were not at par in terms of technical efficiency as well as TGRs. These significant differences were a result of environmental factors that characterize Zambia's provinces.

This study contributes to agricultural productivity literature by being the first to use stochastic meta-frontier techniques to determine the technical efficiency of rice production in Nigeria's upland and lowland farming platforms to account for their subtle environmental heterogeneity. Doing so delivers more credible results for agricultural policy for rice production than from a pooled sample as most previous studies have done [24]. We hypothesize that rice productive efficiency between the lowland and upland regions in Anambra, Nigeria is different because of the prevailing varying environments. Therefore, this study's results may help design policy directed towards increasing rice productivity to curb the ever-rising poverty levels and stagnation in rice productivity among smallholder farmers in Anambra State, similar agro-ecological regions in Nigeria, and other developing countries.

Subsequent sections of the article are organized as follows: The next section presents materials and methods, Section 3 presents empirical results and discussion, and Section 4 concludes.

\section{Materials and Methods}

\subsection{Data}

This study was carried out in the Awka North Local Government Area (LGA) of Anambra State, Nigeria. The LGA headquarters is at Achalla and lies in the latitude of $6.34^{\circ} \mathrm{E}$ and longitude $6.99^{\circ} \mathrm{N}$. The 10 communities in Awka North LGA are Awba Ofemili, Amunuke, Isuaniocha, Amansea, Ebenebe, Uzum, Ugbene, Achala, Mgbakwu, and Ugbenu. Farming is their main occupation, and their major crops are cassava, rice, maize, and yam. A multi-stage sampling technique was used to collect data from a sample of 100 rice farmers comprising 70 upland and 30 lowland rice farmers. In stage one: four communities (Achala, Awba-Ofemili, Amanuke, and Ugbenu) were purposively selected because of their high likelihood of producing rice. In stage two, five villages were randomly selected from each community to make it twenty villages. Furthermore, five rice farmers were randomly selected from each village to make it a total of 100 respondents using structured questionnaires.

Table 1 presents descriptive statistics of rice farmers (which are the decision-making units) in the study regions. The average rice output for upland was $9155.71 \mathrm{~kg}$ (9.16 tons) with a standard deviation (SD) of 4687.75, which is high enough to show variability in rice production in the region. Among the farm inputs utilized from the upland region, fertilizer has the highest mean value $(638.67 \mathrm{~kg})$ followed by labor (235.12 man-days), seed (104 kg), land (2.05 ha), and agrochemicals (16.47 L). The SD for land (0.98) was quite low, which 
implies that land variability within our sample was marginal. It is equally important to note that the average farm size for upland rice production was consistent with [18].

Table 1. Descriptive statistics of farmers.

\begin{tabular}{|c|c|c|c|c|c|c|}
\hline \multirow{2}{*}{ Variable } & \multicolumn{2}{|c|}{ Upland $(n=70)$} & \multicolumn{2}{|c|}{ Lowland $(n=30)$} & \multicolumn{2}{|c|}{ Pooled $(n=100)$} \\
\hline & Mean & Std. Dev. & Mean & Std. Dev. & Mean & Std. Dev. \\
\hline Rice yield (kg) & 9155.714 & 4687.75 & 5893.33 & 3620.48 & 8172 & 4631.72 \\
\hline Fertilizer (kg) & 638.6714 & 279.16 & 328.57 & 205.23 & 545.64 & 295.03 \\
\hline Seed $(\mathrm{kg})$ & 104 & 46.08 & 53.2 & 27.32 & 88.76 & 47.39 \\
\hline Agro-chemicals (liter) & 16.47 & 7.41 & 8.8 & 5.48 & 14.17 & 7.72 \\
\hline Labor (man-day) & 235.12 & 105.66 & 131.87 & 81.85 & 204.14 & 109.57 \\
\hline Land (Ha) & 2.05 & 0.98 & 1.27 & 0.72 & 1.72 & 0.99 \\
\hline Age (year) & 41.93 & 11.52 & 43.2 & 11.19 & 42.65 & 11.22 \\
\hline Household size (No) & 8.87 & 3.34 & 8.7 & 3.13 & 8.87 & 3.24 \\
\hline Farming experience (year) & 11.26 & 3.93 & 14.67 & 5.53 & 12.33 & 4.67 \\
\hline Level of education (year) & 11.64 & 4.17 & 10.87 & 5 & 11.43 & 4.44 \\
\hline $\begin{array}{c}\text { Contact with extension } \\
\text { agent }(\mathrm{No})\end{array}$ & 2.14 & 0.95 & 2.63 & 1.18 & 2.31 & 1.06 \\
\hline Rainfall level () & 3.663 & 0.302 & 3.639 & 0.313 & 3.656 & 0.304 \\
\hline $\begin{array}{c}\text { Gender: (equals } 1 \text { if male, } \\
0 \text { otherwise) }\end{array}$ & $38.6 \%$ & & $30.0 \%$ & & $35.0 \%$ & \\
\hline Female & $61.4 \%$ & & $70.0 \%$ & & $65 \%$ & \\
\hline
\end{tabular}

Regarding the socioeconomic characteristics of the upland rice region, farmers reported an average age and farming experience of 41.93 years and 11.26 years, respectively, which were similar to the sample in Umar et al. [18] and Obianefo et al. [9]. These statistics imply that rice farmers from our study are still in their productive age and are better experienced to handle farming challenges with vigor, which would help them in adopting new technologies including those that may require more labor. On average, household size is 9 people, level of education is 11.64 years, and contacts with extension agents are 2.14 times annually. The majority of rice farmers in our sample indicated that they are female.

In terms of rice yield, lowland rice producers had an average output of $5,893.33 \mathrm{~kg}$ (5.89 tons). Descriptively, average fertilizer, seed, agrochemical, labor, land inputs were $328.57 \mathrm{~kg}, 53 \mathrm{~kg}, 8.8 \mathrm{~L}, 131.87$ man-days, and 1.27 ha, respectively. Regarding demographics, average age, household size, farming experience, level of education, and contact with the extension agents were 43.2 years, 8.7 people, 14.67 years, 10.87 years, and 2.63 times annually, respectively. The sector is female-dominated as well. Descriptive statistics for the whole sample are relatively close to those for the two agro-ecological regions.

\subsection{Analytical Framework}

Efficiency measurement is important due to its direct effect on productivity and economic growth. Efficiency measurement may help farmers to be aware of how they would have to raise their productivity to improve returns [25]. Measurement of firmspecific efficiency through frontier techniques has been severally studied. Frontier analysis sets a maximum limit of potential output levels firms can produce [26]. Though some firms can produce below the frontier point, there cannot be any point above the production frontier given the available technology $[27,28]$. Efficiency implies that firms produce the largest possible quantity of output from a given set of inputs. The theory of efficiency recognizes the pioneering work of Farrell [29] who opined that the efficiency of a firm comprises two components, technical and allocative efficiency, but that a combination of the two components gives a measure of total economic efficiency (overall efficiency). The firm's technical efficiency is the ability to produce maximum output from a minimum quantity of inputs and is either measured as input conserving oriented technical efficiency or output expanding oriented technical efficiency, though a firm's performance is measured stochastically [30]. 
The stochastic production frontier was initially developed by Aigner et al. [31] and has underpinned most applied for farm productivity performance work (e.g., [32-39]). The specification of the stochastic frontier production function allows for the decomposition of the error term into a nonnegative random variable $\left(U_{i}\right)$, associated with the technical inefficiency of the $i$ th farm, as well as the Gaussian error term $\left(V_{i}\right)$, which represents random variation in output due to factors beyond farmers' control, such as variation in weather patterns, measurement error, or any unspecified input variable. More details of the stochastic frontier approach can be found in Aigner et al. [31] and we do not dwell much on it as our focus is the stochastic meta-frontier (SMF) paradigm discussed in the next section.

\subsection{Stochastic Meta-Frontier Analysis}

This study uses Huang et al.'s [40] stochastic meta-frontier model applied in Ng'ombe [22] and Mariko et al. [23] to estimate the optimal output potentials of the rice farming industry in Awka North of Anambra State, Nigeria. The meta-frontier is used to investigate the TE of rice producers facing different production functions in the study area. We equally used a two-step procedure which is what differentiates Huang et al's [40] approach from the classical meta-frontier proposed by Battese et al. [41] and O'Donnell et al. [42].

The first step implies estimating group-specific frontiers, while the second step involves estimating the stochastic meta-frontier production function [22,40]. If the rice industry has $j$ production groups, the stochastic function for the farm or decision-making units is defined by

$$
Y_{j i}=f^{j}\left(X_{1 i}, X_{2 i}, \ldots X_{M i} ; \beta^{j}\right) e^{V_{j i}-U_{j i}}
$$

$j=1,2, \ldots, J ; i=1,2, \ldots, M j$

where $Y_{j i}$ is the observed output of the $i$ th farmer in the $j$ th group, $X_{m i}$ is the $m$ th input quantity used, and $\beta^{j}$ represents the vector of input parameters for the $j$ th group. The production function $(f)$ is superscripted as $j$ to indicate that the individual group-specific frontier can vary across groups in a cross-sectional setup. Group refers to the two agroecological regions (i.e., lowland and upland) considered in the present study. Based on the stochastic frontier model, the $V_{j i}$ is the random error term, denoting statistical noise, and $U_{j i}$ represents technical inefficiency. $V_{j i}$ is assumed to be independent and identically distributed as $N\left(0, \sigma_{v}{ }^{j 2}\right)$; $U_{j i}$ is assumed to be $U_{j i} \sim N^{+}\left(v^{j}\left(Z_{j i}\right), \sigma^{j 2}\right)$, where $Z_{j i}$ represents farmer-specific or group-specific variables [22,43]. Taking logs of both sides of Equation (1), the maximum likelihood estimation (MLE) can be used to estimate the resulting transformed regression model. A farmer's technical efficiency (TE) is defined by

$$
T E_{i}^{j}=\frac{Y_{j i}}{f^{j}\left(X_{j i}\right) e^{V j i}}=e^{-U j i}
$$

where $X_{j i}$ is the input vector of the $i$ th farmer in the $j$ th group and the other variables remain as previously defined. Because it dominates most productivity analysis literature, we assume that $U_{j i}$ follows a half-Gaussian distribution. This entails that farm-specific efficiency is given as 1-TE value [44].

According to Huang et al. [40], the meta-frontier production function that takes into consideration all groups in period $t$ is defined by

$$
f^{M}\left(X_{j i}\right), j=1,2, \ldots, J
$$

The meta-frontier $f^{M}\left(X_{j i}\right)$ envelops the individual group's frontier $f^{j}\left(X_{j i}\right)$. The relationship between the individual group frontier and the meta-frontier is defined in Equation (4) as

$$
f^{j}\left(X_{j i}\right)=f^{M}\left(X_{j i}\right) e^{-U_{j i}^{M}}, \forall j, i
$$


where $U_{j i}^{M} \geq 0$ means that $f^{M} \geq f^{j}$. Additionally, Huang et al. [41] note that the TGR is the ratio of the $j$ th group's production frontier to the meta-frontier and is defined by

$$
T G R_{i}^{j}=\frac{f^{j}(X j i)}{f^{M}(X j i)}=e^{-U_{j i}^{M}} \leq 1
$$

where $T G R_{i}^{j}$ is the gap between the production technology adopted by the rice farmers and the technology available in the rice industry. A higher TGR implies that the gap is closing. According to $\mathrm{Ng}^{\prime}$ ombe [22], a ratio of less than one means that the farmers failed to adopt the most advanced technology, which could be due to some economic or environmental conditions. Accessibility and level of adoption of the available meta-frontier production technology could also affect the value [23,41].

Huang et al. [41] contend that at a particular input level $\left(X_{j i}\right)$, farmers observe the output level $\left(Y_{j i}\right)$ relative to the meta-frontier $f^{M}\left(X_{j i}\right)$ consisting of three components. These are the TGR, the farm's TE, and the random noise as defined by

$$
\frac{Y_{j i t}}{f^{M}\left(X_{j i t}\right)}=T G R_{i}^{j} * T E_{i}^{j} * e^{V_{j i}}
$$

Though, $T G R_{i}^{j} \leq 1$ and $T E_{i}^{j} \leq 1$ are bounded, the meta-frontier $f^{M}\left(X_{j i}\right)$ does not necessarily envelop all the farm's observed outputs $\left(Y_{j i}\right)$ due to the random noise $\left(e^{V_{j i}}\right)$. The $T G R_{i}^{j}$ is equally important to explain the ability of the individual farms in the upland agro-ecological region to compete with other farms in the lowland region. In addition, it corrects the $T E_{i}^{j}$ scores of the farmers that apply different technologies to make them comparable using the distance between the technology (upland and lowland) and the leading frontier. To account for the random noise, Huang et al. [40] rewrite Equation (5) as

$$
M T E_{j i} \equiv \frac{f^{j}\left(X_{j i}\right)}{f^{M}\left(X_{j i}\right)}=T G R_{i}^{j} * T E_{i}^{j}
$$

where $M T E_{j i}$ represents the farm's technical efficiency concerning the meta-frontier production technology $f^{M}\left(X_{j i}\right)$, as opposed to the farm's technical efficiency $\left(T E_{i}^{j}\right)$ regarding group $j^{\prime}$ s production technology $f^{j}\left(X_{j i}\right)$.

\subsection{Empirical Model Specification}

For the sake of brevity and to avoid loss of the degrees of freedom due to our relatively smaller sample size, we adopted the Cobb-Douglas (CD) functional form in all of our estimations. Battese and Broca [45] recommend the Cobb-Douglas functional form to be a more general specification of a non-neutral stochastic production frontier model. As Lee and Tyler [46] put it, the Cobb-Douglas functional form is the basic foundation upon which Aigner et al.'s [31] stochastic frontier modeling is founded and remains an appropriate functional form for efficiency analysis. Our general empirical model is

$$
\operatorname{Ln} Y_{i}=\operatorname{Ln} \beta_{0}+\sum_{j=1}^{5} \beta_{j} \operatorname{Ln} X_{j i}+\left(V_{i}-U_{i}\right)
$$

where $L n$ is the $\log , Y_{i}$ is the level of output $(\mathrm{kg}), X_{1}$ is fertilizer $(\mathrm{kg}), X_{2}$ is the amount of seed ( $\mathrm{kg}), X_{3}$ represents agrochemicals (liters), $X_{4}$ is labor (man-days), and $X_{5}$ is land (hectares). The variable $V_{i}$ is the random error term, $U_{i} \sim N^{+}\left(v_{j}\left(Z_{i}\right)\right) ; Z_{i}$ is farmer-specific that include age, gender, household size, farming experience, education, and extension contacts or environmental-specific characteristics that include high-rainfall dependency. 


\section{Results and Discussion}

\subsection{Hypothesis Tests}

Employing the SMF is appropriate only if a statistical test confirms differences in the underlying technologies between the groups in each industry of interest [40,42]. Using MLE, the value of the log-likelihood function for the stochastic frontier was estimated by pooling data for both zones. Next, the sum of the values of the log-likelihood functions from the individual regional production frontiers was computed to verify if the two agroecological regions used different technologies using the likelihood ratio test (LRT). The rule is that if the null hypothesis of similar technologies across the two regions is rejected, it becomes appropriate to adopt meta-frontier techniques to estimate TE [22,42,47,48]. The LRT statistic was computed as: $\lambda=-2[\ln (\mathrm{L}(\mathrm{Ho}))-(\ln (\mathrm{L}(\mathrm{H} 1))]$, where $\ln (\mathrm{L}(\mathrm{Ho}))$ was the value of the log-likelihood function for stochastic frontiers estimated by pooling data for all regions and $\ln (\mathrm{L}(\mathrm{H} 1))$ was the value of the sum of the log-likelihood values for the two regional production frontiers. The degrees of freedom for the chi-square distribution was six, calculated as the difference between the number of parameters estimated under H1 and Ho. The LRT statistic was 45.581, which was greater than the critical value (12.592) at a $5 \%$ significance level. Thus, we rejected the null hypothesis of homogenous technology between the two agro-ecological regions. This meant that the two regional stochastic frontiers for rice production in Nigeria's Anambra State are different, a result which justified the use of the meta-frontier techniques. We then tested whether estimating a production function without modeling inefficiency was appropriate. We did so by estimating a production function without the inefficiency term and another with the efficiency term. A computed LRT value of $45.58(p<0.001)$ was obtained which resulted in the rejection of the null hypothesis of no presence of inefficiency in the Anambra state. Estimation of all the models was done in Stata $[49,50]$.

\subsection{Estimation of Parameter Estimates of Regional Stochastic Frontiers}

Table 2 shows parameter estimates of the production stochastic frontiers for the two agro-ecological regions (upland and lowland). The lower rows of Table 2 show model statistics. The gamma values of 0.719 and 0.163 are for the upland and lowland regions, respectively. These statistics mean that $71.9 \%$ and $16.3 \%$ deviation from frontier output was coming from the group-specific variables, with the remaining $28.1 \%$ and $83.7 \%$ emanating from the disturbances, respectively.

Table 2. Parameter Estimates for Regional-Specific Stochastic Frontiers.

\begin{tabular}{|c|c|c|c|c|}
\hline \multirow{2}{*}{ Variables } & \multicolumn{2}{|c|}{ Upland Region } & \multicolumn{2}{|c|}{ Lowland Region } \\
\hline & Estimate & Std. Error & Estimate & Std. Error \\
\hline Log-Fertilizer & $0.423^{* * *}$ & 0.137 & $0.248 *$ & 0.132 \\
\hline Log-Seed & -0.031 & 0.110 & 0.068 & 0.165 \\
\hline Log-Agrochemicals & 0.068 & 0.073 & $0.464^{* *}$ & 0.166 \\
\hline Log-Labor & $0.471^{* * *}$ & 0.120 & -0.063 & 0.120 \\
\hline Log-Land & 0.044 & 0.073 & 0.201 & 0.148 \\
\hline Constant & $3.882 * * *$ & 0.489 & $6.340 * * *$ & 0.825 \\
\hline \multicolumn{5}{|l|}{ Region-specific Variables } \\
\hline Age & -0.020 & 0.04 & -0.042 & 0.127 \\
\hline Gender & -0.534 & 0.7 & -4.471 & 7.704 \\
\hline Household size & -0.007 & 0.11 & 0.007 & 0.591 \\
\hline Farming experience & $-0.248^{* *}$ & 0.13 & 0.066 & 0.181 \\
\hline Education & -0.126 & 0.14 & -0.040 & 0.241 \\
\hline Extension contacts & -2.219 & 1.45 & -0.825 & 1.048 \\
\hline Constant & 5.556 & 4.56 & -1.105 & 6.310 \\
\hline \multicolumn{5}{|l|}{ Model statistics } \\
\hline Log-likelihood & 23.927 & & 7.578 & \\
\hline Sigma & 0.035 & & 0.039 & \\
\hline Gamma & 0.719 & & 0.163 & \\
\hline
\end{tabular}

Notes: Asterisks denote significance at the following levels: ${ }^{* * *}=1 \%,{ }^{* *}=5 \%,{ }^{*}=10 \%$. 
For the upland region, results show that fertilizer and labor are the productive resources that significantly influence rice production. The coefficient of the log of fertilizer is positive and statistically significant at a $1 \%$ significance level. This finding implies that a $1 \%$ increase in fertilizer applied to rice plots is associated with an increase in rice output in the upland region by $42.3 \%$, ceteris paribus. In terms of the log of labor, its positive and statistically significant coefficient implies that a $1 \%$ increase in man-days allocated to rice plots would increase rice output by $47.1 \%$, with other factors held constant. These findings are consistent with [9] and [23] and suggest that rice farming in the upland region is fertilizer- and labor-dependent relative to other inputs. Therefore, there is a need for farmers to be encouraged to apply fertilizer and labor to rice fields in a way that is environmentally sustainable.

Regarding results for the lowland region, we find that fertilizer and agrochemicals significantly influence rice production in the region. The coefficient of log of fertilizer is positive and statistically significant at a $10 \%$ significance level, suggesting that a percent increase in fertilizer applied on a rice plot increases rice yield by $24.8 \%$, with other factors held constant. Furthermore, the coefficient of the input log of agrochemicals is equally positive and statistically significant. This finding suggests that a $1 \%$ increase in the use of agrochemical is associated with a $46.4 \%$ increase in rice output in the lowland region, with other factors being fixed. This is plausible because the use of agrochemicals would reduce the weeds that compete with the rice crop for soil nutrients, thereby making more nutrients available for rice. This would likely increase rice yields, a result that is consistent with Mariko et al. [23].

The estimates of group-specific variables are reported at the bottom of Table 2. A group-specific variable with a positive coefficient implies that the variable has a negative effect on technical efficiency. Contrarily, those with negative coefficients mean that the respective variables have a positive effect on technical efficiency. A quick check on these results indicates that farming experience positively and significantly affects technical efficiency in the upland region. All the group-specific variables in the lowland regions have the expected negative signs though they are not statistically significant.

\subsection{Estimation of Parameters of the SMF}

Parameter estimates of the SMF are presented in Table 3. We find that all inputs have significant effects on rice production which highlights their crucial role on rice output in Anambra state, Nigeria. The positive coefficients of the log of fertilizer suggest that ceteris paribus, an additional percent increase in fertilizer applied to rice plots is, on average, associated with a $28.6 \%$ increase in rice output. In terms of log of seeds, when other factors are held constant, a $1 \%$ increase in the amount of seeds of rice planted on rice fields is associated with a $14 \%$ increase in rice yield.

Additionally, as mentioned before, the coefficient of the variable log of agrochemicals is positive and statistically significant at $1 \%$ and implies that an increase in the use of agrochemicals by $1 \%$ would result in an average increase in rice yield by $21.5 \%$, ceteris paribus. Regarding labor, we find that an increase in man-days devoted to rice production is associated with a $17 \%$ increase in rice yield when other factors are held constant, a result that implies the need for farmers to dedicate themselves to rice production activities to increase their rice yield. Furthermore, the land is an equally important resource in rice production. An increase in hectares allocated to rice production by $1 \%$ is associated with an average $12.9 \%$ increase in rice yield, keeping other factors constant by $1 \%$. 
Table 3. Stochastic meta-frontier parameter.

\begin{tabular}{ccc}
\hline Variable Name & \multicolumn{2}{c}{ Anambra State, Nigeria } \\
\cline { 2 - 3 } & Parameter Estimates & Std. Error \\
\hline Log-Fertilizer & $0.286^{* * *}$ & 0.034 \\
Log-Seed & $0.140^{* * *}$ & 0.031 \\
Log-Agrochemicals & $0.215^{* * *}$ & 0.033 \\
Log-Labor & $0.170^{* * *}$ & 0.033 \\
Log-Land & $0.129^{* * *}$ & 0.026 \\
Constant & $5.204^{* * *}$ & 0.144 \\
Environmental-specific variables & -1.687 & 1.334 \\
Rainfall dependent & 0.001 & 4.658 \\
Constant & & \\
Model statistics & 98.398 & \\
Log-likelihood & 0.006 & \\
Sigma & 0.379 & \\
Gamma &
\end{tabular}

Under the model statistics in Table 4, we find that a gamma value of 0.379 , which implies a $37.9 \%$ deviation from the frontier output in the rice industry in Anambra state, Nigeria, is a result of the industry-specific environmental variable: rainfall dependency. We also computed the output elasticities and the return to scale to help identify the stages of classical production that rice farmers are operating on to help influence policy choice. Output elasticity was evaluated as the partial product of the first order derivation of the estimated parameters, while the return to scale was computed as the sum of all the output elasticities. We found output elasticity with respect to labor as the highest for the upland region, while the one with respect to agrochemicals is the highest in the lowland region. Output elasticity with respect to land is the highest in the whole rice industry. In terms of returns to scale, the two regions and rice industry exhibit decreasing returns to scale implying that farmers are producing in the second stage of classical production function and still have the opportunity to increase their production portfolios before reaching their full rice potential. For policy implication, farmers need to scale back their shortterm production costs to stay at the frontier line. Put differently, farmers should reduce their average production costs by expanding their production scale, i.e., cut expenses on inputs that do not seem to contribute significantly to production while ensuring that rice production does not suffer.

Table 4. Estimated output elasticity and return to scale.

\begin{tabular}{cccc}
\hline Output Elasticity & Upland Region & Lowland Region & Rice Industry \\
\hline Log-Fertilizer & 0.423 & 0.248 & 0.247 \\
Log-Seed & -0.031 & 0.068 & 0.107 \\
Log-Agrochemical & 0.068 & 0.464 & 0.201 \\
Log-Labor & 0.471 & -0.063 & 0.069 \\
Log-Land & 0.044 & 0.201 & 0.267 \\
Return to scale & 0.975 & 0.918 & 0.890 \\
\hline
\end{tabular}

\subsection{Estimation of the Technical Efficiency and the Technological Gap Ratios}

Table 5 presents results of the estimated regional TE, meta-frontier technical efficiency (MTE), and the TGRs. We find that mean TE scores from upland and lowland agroecological regions are 0.842 and 0.917 , respectively. The mean difference between these values is statistically significant at a $10 \%$ significance level $(p<0.068)$. These findings imply that rice farmers in the upland region operate at $15.8 \%$ below their optimal capacity while those from the lowland region are operating at $8.3 \%$ below their full potential. The upland region's technical efficiency value is above the 0.792 found in Mariko et al. [23] that is associated with conventional rice production system (CRPS), while the lowland region's value is consistent with their system of rice intensification (SRI) efficiency value of 0.964 . For farmers in the two regions to attain $100 \%$ frontier output, they would have to bridge 
the gap between their current output and the maximum potential output. This would be plausible by addressing the determinants of inefficiency in rice production in the industry by engaging themselves in activities that would enable them to gain some farm managerial skills.

Table 5. Technical efficiency scores and technology gap ratios.

\begin{tabular}{cccccc}
\hline & & Mean & Std. Dev. & Min & Max \\
\hline Upland Region & TE & 0.842 & 0.144 & 0.455 & 0.975 \\
& MTE & 0.994 & 0.005 & 0.964 & 0.998 \\
Lowland Region & TGR & 0.847 & 0.146 & 0.460 & 0.984 \\
& & & & & \\
& TE & 0.917 & 0.058 & 0.784 & 0.976 \\
\multirow{2}{*}{ Rice Industry } & MTE & 0.995 & 0.002 & 0.986 & 0.998 \\
& TGR & 0.921 & 0.058 & 0.787 & 0.981 \\
& TE & 0.875 & 0.113 & 0.499 & 0.978 \\
& MTE & 0.955 & 0.036 & 0.665 & 0.988 \\
& TGR & 0.882 & 0.106 & 0.506 & 0.992 \\
\hline
\end{tabular}

While the variable extension contact is not significantly different from zero, it has a negative sign, something that could be significant to help improve farmers' skills. Learning how to cope with floods and droughts in the upland that may impact their rice production is important for farmers that have different environmental conditions. In terms of MTE, its mean value for the upland and lowland regions are 0.994 and 0.995 , respectively. This implies that on average, lowland region farmers are closer to the industry's potential than their upland counterparts; thus, upland rice farmers would have to increase their production levels to match their lowland counterparts.

Also, the mean TGRs for upland and lowland are 0.847 and 0.921 , respectively with a mean difference being significantly different from zero at a $10 \%$ significance level $(p<0.059)$. This implies that the upland and the lowland region farmers will respectively have to close the $15.3 \%$ and $7.9 \%$ gaps to be technically efficient. As suggested by $\mathrm{Ng}^{\prime}$ ombe [22], farmers with TGR equal to unity adopted the most advanced technologies in the industry. Therefore, the lowland region farmer's frontier output is closer to being tangent to their meta-frontier output than their upland counterpart. Thus, upland region farmers are distant to metafrontier than lowland region farmers. Furthermore, the rice industry's TE and TGR are 0.875 and 0.882 respectively. This result implies that the rice industry is operating $12.5 \%$ below the optimal capacity but needs to close the $11.8 \%$ gap to be technically efficient before their average optimal rice output is equivalent to regional optimal production levels.

\section{Conclusions}

This study used stochastic meta-frontier techniques to compare the technical efficiency (TE) and technological gap ratios (TGRs) of rice production in the Awka North Local Government Area of Anambra State, Nigeria. Our findings revealed that lowland rice farmers are more technically efficient and overall less distant to the meta-frontier than upland rice farmers. This suggests that compared with their counterparts, upland rice farmers need to improve their rice production. Our results show that as farmers from the upland gain more experience in rice production, their TE would increase, with all other things held fixed. In addition, an increased number of man-days allocated to rice production by upland farmers would also result in increased rice production. This result implies that relevant stakeholders need to promote rice farming in the upland by creating incentives such as increased rice prices and available markets so that more farmers from the upland would be encouraged to dedicate themselves to rice farming. As farmers from the upland spend more time on rice farming, it would improve their farming experience which is expected to close the TE gap with lowland as well as the overall industry. Additionally, the increased experience would help them improve their farm managerial skills and ways 
of dealing with and mitigating production risks [47,51]. If lowland farmers are incentivized in the same way, they would also increase their rice productivity and TE levels.

We found that for both farmers, increased fertilizer use would increase their rice output. The same holds for the industry. However, smallholder farmers have limited resources and the government may have to help them with subsidized fertilizer as well as other inputs such as agrochemicals to help them expand their rice production scale. That the respective technical efficiency scores for rice farmers from both agro-ecological regions are still far from the stochastic meta-frontier is an indication of the need of governments and other relevant authorities to provide necessary rice production-related information to help reduce the gap [52-55]. Information may be provided through farmer trainings with a focus on relevant rice technologies, especially with the technologies that fit the working environment of the lagging area (i.e., upland). Such technologies may include improved rice varieties, crop diversification, mixed cropping systems, and other sustainable land management strategies $[56,57]$ that are associated with improved rice productivity for environments similar to lowland's agro-ecology.

Another avenue for policymakers is to provide subsidized improved rice varieties to both regions to help improve farmer access to such seeds. This is important because subsidized inputs with more intensive and export-oriented farming may boost agricultural returns [58]. We further found that rice farmers in both regions and the industry as a whole operate in the second stage of the classical production function. This suggests that there is a need for the farmers to reduce their short-run production costs while ensuring that the rice production scale is maintained to optimize profit. As in every empirical work, caveats in this study remain. Future studies should focus on employing panel data to help account for unobserved heterogeneity to improve our results. However, this study's results lay a launchpad for policymakers aiming to improve productivity in Anambra State and for future studies seeking to investigate resource efficiency in developing world countries.

Author Contributions: Conceptualization, C.A.O. and J.N.N.; Data curation, C.A.O. and J.N.N.; Formal analysis, C.A.O., J.N.N. and A.M.; Funding acquisition, C.A.O., J.N.N., A.M., B.M., N.J.O. and N.J.O.; Investigation, C.A.O., J.N.N., A.M., B.M., N.J.O. and O.O.A.; Methodology, C.A.O. and J.N.N.; Project administration, C.A.O. and J.N.N.; Resources, C.A.O., J.N.N., A.M., B.M., N.J.O. and O.O.A.; Software, C.A.O. and J.N.N.; Supervision, C.A.O. and J.N.N.; Validation, C.A.O., J.N.N., A.M., B.M., N.J.O. and O.O.A.; Visualization, C.A.O., J.N.N., A.M., B.M., N.J.O. and O.O.A.; original draft, C.A.O., J.N.N. and A.M.; Writing-review \& editing, C.A.O., J.N.N., A.M., B.M., N.J.O. and O.O.A. All authors have read and agreed to the published version of the manuscript.

Funding: This research received no external funding.

Institutional Review Board Statement: Not applicable.

Informed Consent Statement: Not applicable.

Data Availability Statement: Data are available upon reasonable request from the corresponding author.

Conflicts of Interest: The authors declare no conflict of interest.

\section{References}

1. Osmani, A.G.; Hossain, E. Market participation decision of smallholder's farmers and its determinants in Bangladesh. Econ. Agric. 2015, 62, 163-179.

2. Anumudu, O.O.; Obianefo, C.A.; Okafor, I.P.; Onyekineso, J.C. Determinants of market participation and failure of table egg production by small scale poultry farmers in Anambra State, Nigeria. Int. J. Sci. Res. PONTE 2020, 76, 58-77.

3. Mulungu, K.; Ng'ombe, J.N. Sources of economic growth in Zambia, 1970-2013: A growth accounting approach. Economies 2017, 5, 15. [CrossRef]

4. Frimawaty, E.; Basukriadi, A.; Syamsu, A.J.; Soesilo Budhi, T.E. Sustainability of rice farming based on eco-farming to face food security and climate change: Case study in Jambi Province, Indonesia. Procedia Environ. Sci. 2013, 17, 53-59. [CrossRef]

5. Taridala, S.A.A.; Abdullah, W.G.; Wahyuni, S.; Wianti, N.I.; Zani, M. Understanding the social and economic aspects of upland rice farming. Earth Environ. Sci. 2018, 122, 1-8. [CrossRef] 
6. Ike, P.C.; Ugwumba, C.O. The profitability of small-scale broiler production in Onitsha North Local Government Area of Anambra State, Nigeria. Int. J. Poult. Sci. 2015, 10, 106-109. [CrossRef]

7. Egbetokun, O.A.; Sittu, B.A.; Ayode, M.O. Determinants of market participation among maize farmer's in Ogbomoso Zone, Oyo State, Nigeria. Cercet. Agron. Mold. 2017, 2017, 109-118. [CrossRef]

8. Obianefo, C.A.; Aguaguiyi, N.F.; Umebali, E.E.; Ezeano, C.I. Comparative analysis of rainfed and dry season rice farming in value chain development programme in Ayamelum Local Government Area Anambra State. Inter J. Sci. Res. 2019, 8, $1655-1659$.

9. Obianefo, C.A.; Nwigwe, C.A.; Meludu, T.N.; Anyasie, I.C. Technical efficiency of rice farmers in Anambra State value chain development programme. J. Dev. Agric. Econ. 2020, 12, 67-74. [CrossRef]

10. Nwinya, C.E.; Obienusi, E.A.; Onuoha, D.C. Comparative economic analysis of upland and lowland rice production in Izzi Local Government Area of Ebonyi State. J. Econ. Sustain. Dev. 2014, 5, 144-160.

11. Ayambila, N.S.; Kwadzo, M.T.G.; Brempong-Asuming, S. Economics of rice production an economic analysis of rice production systems in the Upper East region of Ghana. Ghana J. Dev. Stud. 2008, 5, 95-108. [CrossRef]

12. Chen, S.; Zheng, X.; Wang, D.; Chen, L.; Xu, C.; Zhang, X. Effect of long-term paddy- upland yearly rotations on rice (Oryza sativa) yield, soil properties, and bacteria community diversity. Sci. World J. 2012, 2012, 279641. [CrossRef] [PubMed]

13. Saputra, E.; Tabrani, G.; Zuhry, E. The Experiment of Bokashi and Ferinsa Composition on Upland Red Rice (Oryza nivara L.) Inpago 7 Variety. JOM Faperta 2016, 3, 1-13.

14. The World Bank. Pairing Agriculture with Technology in Bangladesh. Available online: www.worldbank.org/en/news/feature/ 2014/06/23/pairing-agriculture-with-technology-in-banglashe (accessed on 23 June 2014).

15. Shehu, J.F.; Mshelia, S.I.; Tashikalma, A.K. Analysis of technical efficiency of small-scale rain-fed upland rice farmers in North-west agricultural zone of Adamawa state, Nigeria. J. Agric. Soc. Sci. 2007, 3, 133-136.

16. Oluwadamilola, K.A. Challenges of rice production in Nigeria: A case study of Kogi State. Department of Science and Technology, National Defense College Abuja, Nigeria. Food Sci. Qual. Manag. 2018, 74, 1-16.

17. IFAD. Value Chain Development Programme. Available online: https://www.ifad.org/en/web/operations/-/project/11000015 94 (accessed on 4 July 2020).

18. Umar, M.F.; Nugroho, I.; Darmadji, S. The study of entrepreneurship and innovation adoption by farmer in improving lowland rice farming. J. Socioecon. Dev. 2020, 3, 16-28. [CrossRef]

19. Rohmad, B.; Praptiningsih, G.A. Efficiency analysis of production factors utilization in upland rice farming in NRLS Conference Proceedings. KnE Life Sci. 2017, 2017, 180-187.

20. Willybrordus, L. Measurement of economic efficiency of upland rice farming in different land ownership status in Mausambi Village, Maurole Sub- District, Ende Regency. J. AGRISEP 2019, 18, 387-402.

21. Yurkushi, E.N. Comparative Economic Analysis of Upland and Lowland Rice Production in Selected Local Government Area of Kaduna State, Nigeria. Ph.D. Thesis, Ahmadu Bello University, Zaria, Nigeria, 2015.

22. Ng'ombe, J.N. Technical efficiency of smallholder maize production in Zambia: A stochastic meta-frontier approach. Agrekon 2017, 56, 347-365. [CrossRef]

23. Mariko, K.; Moussa, M.; Li, X.; Matafwali, E.; John-Philippe, E.A.; Ekram, A.E.; Osewe, M.O. Stochastic meta frontier analysis of smallholder rice farmers' technical efficiency. J. Agric. Sci. 2019, 11, 31-44. [CrossRef]

24. Battese, G.E.; Rao, D.P. Technology gap, efficiency, and a stochastic metafrontier function. Int. J. Bus. Econ. $2002,1,87$.

25. Mzyece, A.; Ng'ombe, J.N. Does crop diversification involve a trade-off between technical efficiency and income stability for rural farmers? Evidence from Zambia. Agronomy 2020, 10, 1875. [CrossRef]

26. Forsund, F.R.; Lovell, C.A.K.; Schmidt, P. A survey of frontier production functions and their relationships to efficiency measurement. J. Econom. 1980, 13, 5-25. [CrossRef]

27. Ume, S.I.; Ochiaka, J.S. Technical efficiency of catfish production among smallholder Farmers in Anambra State of Nigeria. Case Stud. J. 2016, 5, 147-155.

28. Mzyece, A.; Ng'ombe, J.N. Crop diversification improves technical efficiency and reduces income variability in Northern Ghana. J. Agric. Food Res. 2021, 5, 100162. [CrossRef]

29. Farrel, M. The measurement of productive efficiency. J. R. Stat. Soc. 1957, 3, 253-290. [CrossRef]

30. Jondrow, J.C.A.; Lovell, L.S.; Schmidt, P.S. On the Estimation of technical inefficiency in the stochastic frontier production function model. J. Econom. 1982, 19, 233-238. [CrossRef]

31. Aigner, D.J.; Lovell, C.A.; Schmidt, P. Formulation and estimation of stochastic frontier production function model. J. Econom. 1977, 1, 21-37. [CrossRef]

32. Battese, G.E.; Coelli, T.J. Frontier production functions, technical efficiency and panel data: With application to paddy farmers in India. J. Pro. Anal. 1992, 3, 153-169. [CrossRef]

33. Chiona, S.; Kalinda, T.; Tembo, G. Stochastic frontier analysis of the technical efficiency of smallholder maize farmers in Central Province, Zambia. J. Agric. Sci. 2014, 6, 108-118. [CrossRef]

34. Souleymane, O. Technical and economic efficiency of rice production in the Kou valley (Burkina Faso): Stochastic frontier approach. Asian J. Agric. Rural Dev. 2015, 5, 53-63.

35. Ng'ombe, J.; Kalinda, T.A. Stochastic frontier analysis of technical efficiency of maize production under minimum tillage in Zambia. Sustain. Agric. Res. 2015, 5, 31-46. [CrossRef] 
36. Bidzakin, J.K.; Fialor, S.C.; Awunyo-Vitor, D.; Yahaya, I. Impact of irrigation ecology on rice production efficiency in Ghana. Adv. Agric. 2018, 2018, 5287138. [CrossRef]

37. Raimondo, M.; Caracciolo, F.; Nazzaro, C.; Marotta, G. Organic Farming Increases the Technical Efficiency of Olive Farms in Italy. Agriculture 2021, 11, 209. [CrossRef]

38. Liu, J.; Dong, C.; Liu, S.; Rahman, S.; Sriboonchitta, S. Sources of Total-Factor Productivity and Efficiency Changes in China's Agriculture. Agriculture 2020, 10, 279. [CrossRef]

39. Obi, A.; Ayodeji, B.T. Determinants of economic farm-size-efficiency relationship in smallholder maize farms in the Eastern Cape Province of South Africa. Agriculture 2020, 10, 98. [CrossRef]

40. Huang, C.J.; Huang, T.H.; Liu, N.H. A new approach to estimating the metafrontier production function based on a stochastic frontier framework. J. Pro. Anal. 2014, 42, 241-254. [CrossRef]

41. Battese, G.E.; Rao, D.P.; O'donnell, C.J. A metafrontier production function for estimation of technical efficiencies and technology gaps for firms operating under different technologies. J. Pro. Anal. 2004, 21, 91-103. [CrossRef]

42. O'Donnell, C.J.; Rao, D.P.; Battese, G.E. Metafrontier frameworks for the study of firm-level efficiencies and technology ratios. Empir. Econ. 2008, 34, 231-255. [CrossRef]

43. Osawe, O.W.; Adeqeye-Bolarin, A.J.; Omonona-Bolarin, O. Technical efficiency of small scale farmers: An application of the stochastic frontier production function on fish farmers in Ibadan Metropolis. J. Econ. Rural Dev. 2008, 16, 71-82. [CrossRef]

44. Assa, M.M.; Abdi-Khalil, E.; Matchaya, G.C. Unexploited Profit among smallholder farmers in Central Malawi: What are the sources? Int. J. Appl. Econ. 2012, 9, 83-95.

45. Battese, G.E.; Broca, S.S. Functional forms of stochastic frontier production functions and models for technical inefficiency effects: A comparative study for wheat farmers in Pakistan. J. Pro. Anal. 1997, 8, 395-414. [CrossRef]

46. Lee, L.; Tyler, F.W.G. The stochastic frontier production function and average efficiency: An empirical analysis. J. Econom. 1978, 7, 385-389. [CrossRef]

47. Mensah, A.; Brümmer, B. Drivers of technical efficiency and technology gaps in Ghana's mango production sector: A stochastic metafrontier approach Amos. Afr. J. Agric. Resour. Econ. 2016, 11, 101-117.

48. Huang, T.H.; Chiang, D.L.; Tsai, C.M. Applying the new metafrontier directional distance function to compare banking efficiencies in Central and Eastern European countries. Econ. Model. 2015, 44, 188-199. [CrossRef]

49. Belotti, F.; Daidone, S.; Ilardi, G.; Atella, V. Stochastic frontier analysis using Stata. Stata J. 2013, 13, 719-758. [CrossRef]

50. StataCorp. Stata Statistical Software: Release 16; StataCorp LLC: College Station, TX, USA, 2019.

51. Ng'ombe, J.N.; Tembo, M.C.; Masasi, B. "Are they aware, and why?" Bayesian analysis of predictors of smallholder farmers' awareness of climate change and its risks to agriculture. Agronomy 2020, 10, 376. [CrossRef]

52. Alem, H.; Lien, G.; Hardaker, J.B.; Guttormsen, A. Regional differences in technical efficiency and technological gap of Norwegian dairy farms: A stochastic meta-frontier model. Appl. Econ. 2019, 51, 409-421. [CrossRef]

53. Manda, J.; Alene, A.D.; Gardebroek, C.; Kassie, M.; Tembo, G. Adoption and impacts of sustainable agricultural practices on maize yields and incomes: Evidence from rural Zambia. J. Agric. L. Econ. 2016, 67, 130-153. [CrossRef]

54. Mulungu, K.; Tembo, G. Effects of weather variability on crop abandonment. Sustainability 2015, 7, 2858-2870. [CrossRef]

55. Lu, W.; Addai, K.N.; Ng'ombe, J.N. Impact of improved rice varieties on household food security in Northern Ghana: A doubly robust analysis. J. Int. Dev. 2021, 33, 342-359. [CrossRef]

56. Masasi, B.; Taghvaeian, S.; Boman, R.; Moriasi, D.N.; Starks, P.J. Impacts of variable irrigation regimes on cotton yield and fiber quality. Agric. Environ. Lett. 2020, 5, e20031. [CrossRef]

57. Lu, W.; Addai, K.N.; Ng'ombe, J.N. Does the use of multiple agricultural technologies affect household welfare? Evidence from Northern Ghana. Agrekon 2021, 60, 1-18. [CrossRef]

58. Abman, R.; Carney, C. Agricultural productivity and deforestation: Evidence from input subsidies and ethnic favoritism in Malawi. J. Environ. Econ. Manag. 2020, 103, 102342. [CrossRef] 